\title{
Interzeolite transformation from FAU to CHA and MFI zeolites monitored by UV Raman spectroscopy
}

\author{
Juan Zhang a, Yueying Chu c, Xiaolong Liu d, Hao Xu a, Xiangju Meng a,*, Zhaochi Feng b,\$, \\ Feng-Shou Xiao a,\# \\ a Department of Chemistry, Key Lab of Applied Chemistry of Zhejiang Province, Zhejiang University, Hangzhou 310028, Zhejiang, China \\ b State Key Laboratory of Catalysis, Dalian Institute of Chemical Physics, Chinese Academy of Sciences, Dalian 116023, Liaoning, China \\ c State Key Laboratory of Magnetic Resonance and Atomic and Molecular Physics, Wuhan Institute of Physics and Mathematics, Chinese Academy of \\ Sciences, Wuhan 430071, Hubei, China \\ d School of Materials Science and Engineering, Sun Yat-Sun University, Guangzhou 510275, Guangdong, China
}

\section{A R T I C L E I N F O}

\section{Article history:}

Received 10 January 2019

Accepted 25 February 2019

Published 5 December 2019

\section{Keywords:}

Interzeolite transformation

UV Raman spectroscopy

DFT calculation

Double 6-memberred rings

Decomposition and re-assembly

\begin{abstract}
A B S T R A C T
As a powerful and sensitive tool for the characterization of zeolite building units, UV Raman spectroscopy has been used to monitor interzeolite transformation from FAU to CHA and MFI zeolites. The results show that the behavior of double 6-membered rings (D6Rs) in the FAU zeolite framework plays an important role during the formation of the target product in the interzeolite transformation. For the transformation of FAU to CHA, because both zeolites contain the same D6R units, direct transformation occurs, in which the D6Rs were largely unchanged. In contrast, for the transformation of FAU to MFI, the D6Rs can be divided into two single 6-membered rings (S6Rs), which further assembled into the MFI structure. In this crystallization, 5-membered rings (5Rs) are only observed in the MFI framework formation, suggesting that the basic building units in the transformation of FAU to MFI are S6Rs rather than 5Rs. These insights will be helpful for further understanding of the interzeolite transformation.
\end{abstract}

(C) 2019, Dalian Institute of Chemical Physics, Chinese Academy of Sciences. Published by Elsevier B.V. All rights reserved.

\section{Introduction}

Zeolites are useful inorganic crystalline materials that have been widely applied for shape selective catalysis, adsorption, separation, ion exchange, and adsorption processes due to their versatile ordered pore structure, large specific surface area, high thermal and hydrothermal stability, controllable acid center skeleton, and exchangeable cations [1-4]. Most zeolites are synthesized under hydrothermal conditions from conventional amorphous aluminosilicate gels [5-8]. Recently, interzeolite transformation between zeolites has attracted significant attention owing to its benefits including relatively short crystallization time and specific zeolite structures such as CHA, AEI, and RTH that can be formed [9-12]. Generally, FAU zeolites with high silica to alumina ratios (SARs) are chosen as a starting material, where a large amount of orderly connected double 6-membered ring (D6R) units in the FAU framework play an important role during the transformation process $[13,14]$. In

\footnotetext{
* Corresponding author. Tel/Fax: +86-571-8273698; E-mail: mengxj@zju.edu.cn

\# Corresponding author. Tel/Fax: +86-571-8273698; E-mail: fsxiao@zju.edu.cn

\$Corresponding author. Tel/Fax: +86-411-84694447; E-mail: zcfeng@dicp.ac.cn

This work was supported by the National Key R\&D Program of China (2017YFB0702800), the National Natural Science Foundation of China (2152780065, 91634201 and 21720102001), and the Strategic Priority Research Program of Chinese Academy of Sciences (XDB17000000). DOI: S1872-2067(19)63287-0 | http://www.sciencedirect.com/science/journal/18722067 | Chin. J. Catal., Vol. 40, No. 12, December 2019
} 
addition, many successful examples of interzeolite transformation from FAU zeolites to other zeolite structures without D6R units (such as RUT, MER, and MWW) have been reported [15-17]. Currently, it is still challenging to investigate the behavior of D6Rs during interzeolite transformation.

Over the past decades, various techniques have been developed for identification of possible intermediates and mechanisms of zeolite crystallization, including X-ray diffraction and scattering [18], solid-state/liquid-state NMR spectroscopy $[19,20]$, mass spectrometry $[21,22]$, atomic force microscopy $[23,24]$, and electron microscopy $[25,26]$. Compared to these techniques, UV Raman spectroscopy has certain advantages in terms of avoiding fluorescence and increasing sensitivity [27] and has proven to be a powerful technique to characterize zeolite crystallization because of its unique sensitivity to framework vibrations, particularly the ring structure. Therefore, it can provide structural information based on vibrational motion of the framework, even during the well-known "induction period" in zeolite synthesis, a "black" stage in terms of XRD pattern data $[28,29]$. Unfortunately, no characterization of interzeolite transformation by UV Raman spectroscopy has been published to date.

In this study, UV Raman spectroscopy was used to monitor the behavior of the D6R units during the interzeolite transformation from FAU to CHA and MFI, showing that the D6R units basically remained during the transformation from FAU into CHA while they were divided to S6R units then into MFI structure during the transformation from FAU into MFI.

\section{Experimental}

\subsection{Characterization}

Powder X-ray powder diffraction (PXRD) patterns were measured using a Rigaku Ultimate VI X-ray diffractometer (40 $\mathrm{kV}, 40 \mathrm{~mA})$ with $\mathrm{Cu} K_{\alpha}(\lambda=1.5406 \AA)$ radiation. The UV Raman spectra were recorded using a home-assembled UV Raman spectrograph with a Jobin-Yvon T64000 triple-stage spectrograph with a spectral resolution of $2 \mathrm{~cm}^{-1}$. The single-frequency UV laser line at $266 \mathrm{~nm}$ originated from an efficient external cavity frequency doubler (Wavetrain, Spectra-Physics) of a single-frequency laser at $532 \mathrm{~nm}$ laser (Verdi 2, Coherent). The excitation source with an output of $30 \mathrm{~mW}$ was used and the power of the laser at was approximately $3.0 \mathrm{~mW}$.

\subsection{Computational studies}

The frequency of the D6R structure extracted from the FAU crystallographic data was calculated using the B3LYP hybrid exchange-correlation functional. Geometry optimizations were performed at the basis set of $6-311+G(d, p)$. Frequency analysis was then performed to confirm the stability of the optimized molecular structures, and the enthalpies were then calculated from harmonic frequencies. All calculations were performed using the Gaussian 09 package [30]. The terminal 0 atoms were saturated with $\mathrm{H}$ atoms, which were positioned on the vector from the $\mathrm{O}$ to $\mathrm{Si}$ atom that the $\mathrm{H}$ was replacing. During struc- ture optimization, all framework atoms were relaxed while the terminal $\mathrm{H}$ atoms were fixed to preserve the integrity of the zeolite structure.

\section{Results and discussion}

The topological structures of FAU and the targets (CHA and MFI) are shown in Fig. 1. FAU and CHA share the same basic structural building blocks (D6R), but no D6R units exist in the framework of MFI. Therefore, the discussion regarding the D6R behavior will be divided into two parts, i.e. the target structures with and without D6R.

\subsection{Transformation of FAU to $\mathrm{CHA}$}

Figure 2a shows the UV Raman spectra of the interzeolite transformation from FAU to CHA zeolite. Between 0 and $6 \mathrm{~h}$, three main Raman bands were observed belonging to vibrations of the FAU framework (Fig. S1 in the Supporting Information), yielding a sharp Raman band at $500 \mathrm{~cm}^{-1}$ that could be assigned to the breathing mode vibration of the 4-membered ring (4R) in the FAU crystalline framework [31,32]. The band at $298 \mathrm{~cm}^{-1}$ was attributed to the bending mode of D6R in the FAU framework [33,34], and a new shoulder band was observed at $480 \mathrm{~cm}^{-1}$, which has not previously been reported for FAU with low SAR. DFT calculations were performed which verified that this new band could be attributed to the frequency of the breathing vibration mode of the $4 \mathrm{R}$ in D6R with much higher Raman activity.

When the crystallization time reached $6 \mathrm{~h}$, two new Raman bands appeared at approximately 465 and $330 \mathrm{~cm}^{-1}$ in accordance with the weak XRD peaks at $9.6^{\circ}, 16.2^{\circ}$ and $20.8^{\circ}$ associated with the CHA framework (Fig. S1). The band at $465 \mathrm{~cm}^{-1}$ was attributed to $4 \mathrm{R}$ in the CHA structure, which became stronger with increasing crystallization time [35]. Meanwhile, the intensity of the $500 \mathrm{~cm}^{-1}$ band gradually decreased and eventually vanished, indicating that the 4 Rs in the FAU structure were gradually transferred into 4Rs in the CHA structure. Interestingly, the intensities of the characteristic D6R bands
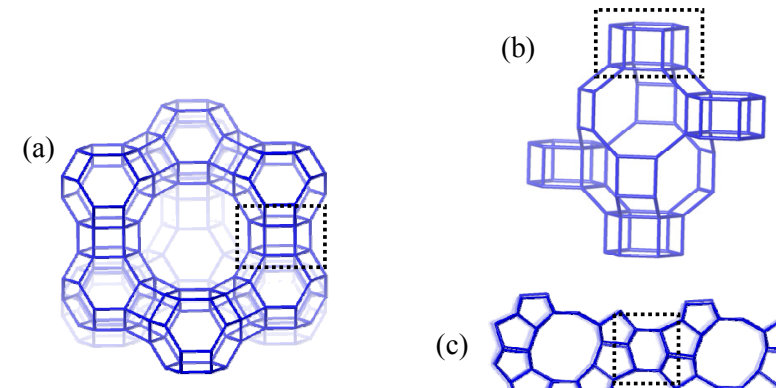

(c)

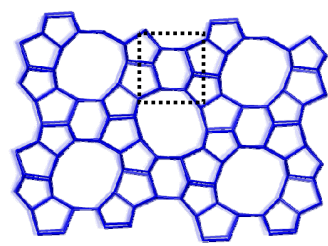

Fig. 1. Framework structure of (a) FAU, (b) CHA, and (c) MFI zeolites. The dotted-line squares indicate the common composite building units (D6R and S6R) of the three zeolites. 

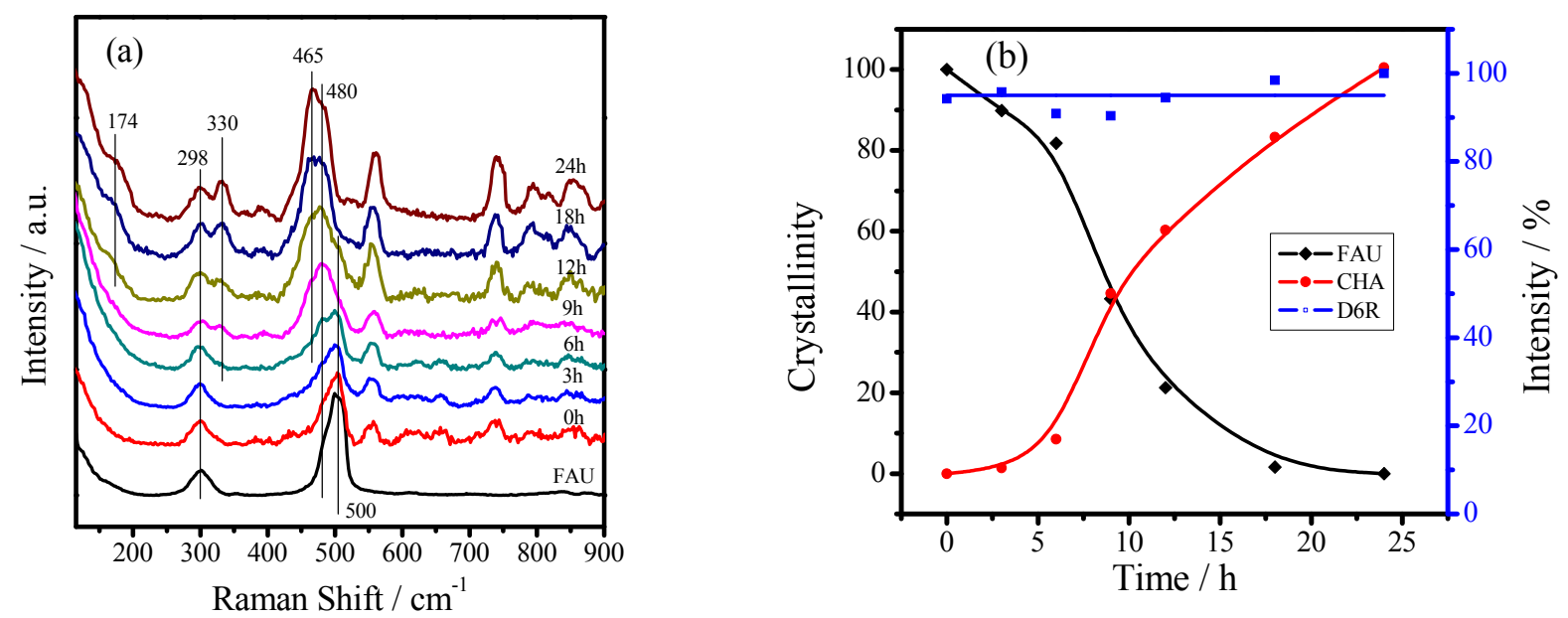

Fig. 2. (a) UV Raman spectra of the solid products synthesized under different crystallization conditions and (b) FAU/CHA crystallinity and intensity of the selected band $\left(298 \mathrm{~cm}^{-1}\right)$ as a function of crystallization time during the interzeolite transformation of FAU into CHA.

(298 and $480 \mathrm{~cm}^{-1}$ ) were remained nearly identical because D6R units exist in both FAU and CHA frameworks. In addition, a novel band at $330 \mathrm{~cm}^{-1}$ appeared, which was attributed to D6R in the CHA structure [36,37]. The intensity of this band strengthened with increasing crystallization time.

Figure $2 \mathrm{~b}$ shows the FAU and CHA crystallinity and intensity of the selected band $\left(298 \mathrm{~cm}^{-1}\right)$ as a function of crystallization time. With increasing crystallization time, the crystallinity of the FAU zeolite significantly decreased, which was accompanied by a corresponding increase of the CHA zeolite crystallinity. Interestingly, although there was a conversion balance of the two crystalline phases during the transformation, the intensity of the D6R species largely remained the same within the experimental error range. This indicated that the D6R structure was stable and the D6R structural integrity was maintained rather than decomposed during the conversion from FAU to CHA. These results provide direct evidence for the transfor- mation of D6R units from the FAU to CHA structure.

\subsection{Transformation of FAU to MFI}

Figure 3a shows the UV Raman spectra of the interzeolite transformation from FAU to MFI zeolite. As mentioned previously, the Raman spectrum of the FAU zeolite only showed bands at 500, 480, and $298 \mathrm{~cm}^{-1}$. After crystallization for $3 \mathrm{~h}$ during the transformation to MFI, the Raman bands associated with the characteristic vibrations of the MFI zeolite framework (433 and $475 \mathrm{~cm}^{-1}$ for $4 \mathrm{R}, 289 \mathrm{~cm}^{-1}$ for S6R, and $377 \mathrm{~cm}^{-1}$ for the $5 R$ units in the crystal phase) gradually appeared [38-41]. Simultaneously, the XRD patterns of the samples exhibited clear characteristic peaks of the zeolite MFI framework (Fig. S2 in the Supporting Information). Unlike the interzeolite transformation from FAU to CHA, the Raman spectra of the interzeolite transformation between FAU and MFI showed an apparent
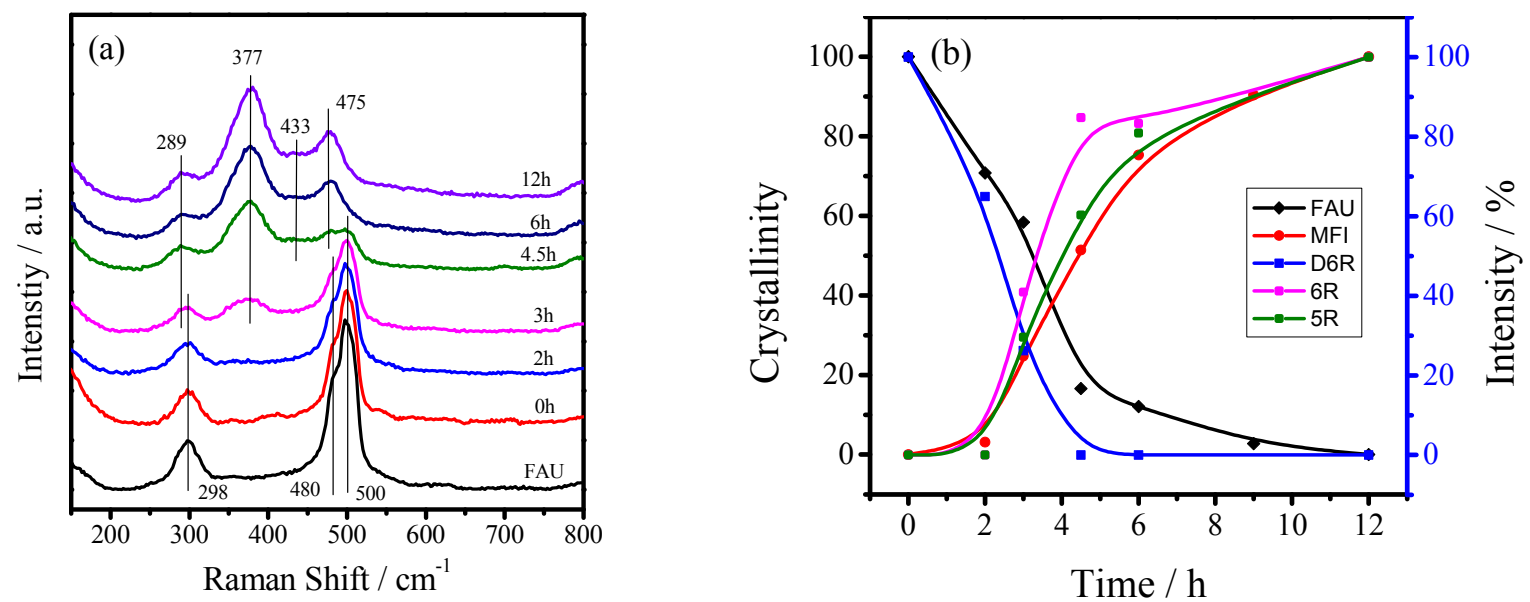

Fig. 3. (a) UV Raman spectra of the solid products synthesized under different crystallization conditions and (b) FAU/MFI crystallinity and intensity of the 298, 289, and $377 \mathrm{~cm}^{-1}$ bands as a function of crystallization time during the interzeolite transformation from FAU to MFI. 
and parallel reduction in the band intensities at 500, 298, and $480 \mathrm{~cm}^{-1}$. These bands disappeared when the MFI zeolite dominated crystalline phase in the product, indicating that the D6R structure was unstable during this process and was decomposed.

Figure $3 \mathrm{~b}$ shows the FAU/MFI crystallinity and intensity of selected Raman bands $\left(298,289\right.$, and $\left.377 \mathrm{~cm}^{-1}\right)$ as a function of crystallization time. With increasing crystallization time, the crystallinity of the FAU zeolite decreased and the intensity of the D6R structure significantly decreased and eventually completely vanished before the disappearance of FAU structure, suggesting that the D6R was unstable and likely decomposed into smaller species during the transformation. Interestingly, the emergence of the S6R units occurred earlier than the formation of MFI crystallites, where the concentration of S6R units increased sharply and reached a maximum in a very short time. Thus, it is reasonable to infer that the S6R units exist during the crystal nucleation period and participated in the nucleation. Moreover, the growth rate of the $5 \mathrm{R}$ units approximates the crystallinity of the MFI zeolite, indicating that the formation of $5 \mathrm{R}$ units occurs during MFI crystallization from the assembly of S6Rs. These results suggest that the D6R structure decomposed into S6R units instead of 4R units during the formation of MFI structure, while the $5 R$ units were only observed after formation of MFI crystals.

\subsection{DFT calculations of the decomposition mode of D6R}

It is well known that DFT calculations can be used to explore the reaction activities of zeolites [42,43]. Herein DFT was used to investigate the D6R hydrolysis in FAU zeolite, as shown in Fig. 4. Two hydrolysis processes are proposed for the D6R units: (i) D6R hydrolysis to form two S6Rs and six $\mathrm{H}_{2} \mathrm{O}$ molecules, and (ii) D6R hydrolysis to form three S4Rs and six $\mathrm{H}_{2} \mathrm{O}$ molecules. Figure $4 \mathrm{a}$ and $4 \mathrm{~b}$ provide the optimized geometries and corresponding reaction enthalpies of the proposed hy-
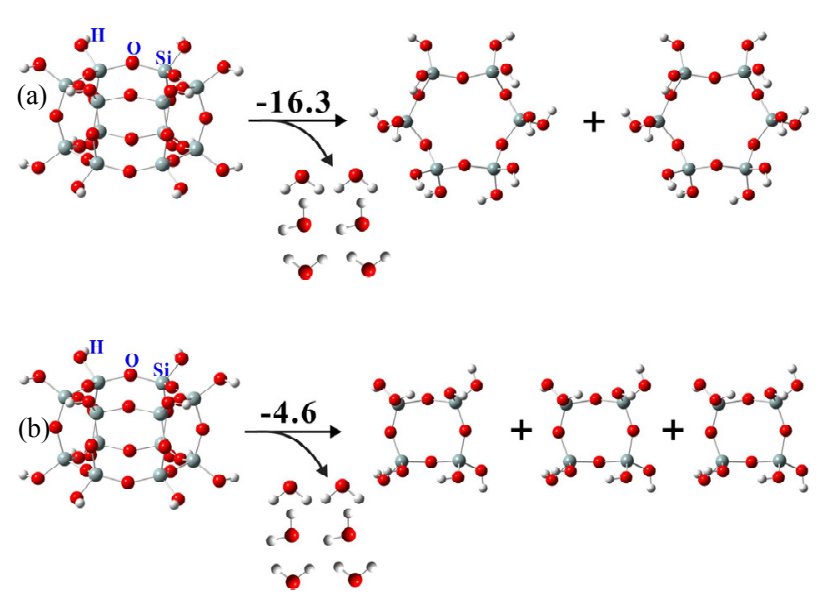

Fig. 4. Optimized structures involved in the D6R hydrolysis to form (a) two S6Rs and (b) three 4Rs. The reaction enthalpy is provided in units of $\mathrm{kcal} / \mathrm{mol}$.

drolysis processes. The calculated reaction enthalpies for D6R hydrolysis into two S6Rs $(-16.3 \mathrm{kcal} / \mathrm{mol})$ was significantly lower than that form three $4 \mathrm{Rs}(-4.6 \mathrm{kcal} / \mathrm{mol})$, indicating that D6R hydrolysis to form two S6Rs is preferable, in good agreement with the experimental UV Raman results (Fig. 2 and 3).

According to the results presented above, the possible pathways of interzeolite transformation from FAU to CHA and MFI zeolites are proposed in Fig. 5. Depending on the structural similarity between the staring and target zeolites, the D6R units of the FAU zeolite display two responses: a direct transformation to CHA, or decomposition into S6R and adoption of the MFI structure.

\section{Conclusions}

In summary, interzeolite transformation from FAU to CHA and MFI zeolites was carefully investigated by UV Raman spec-

(b)

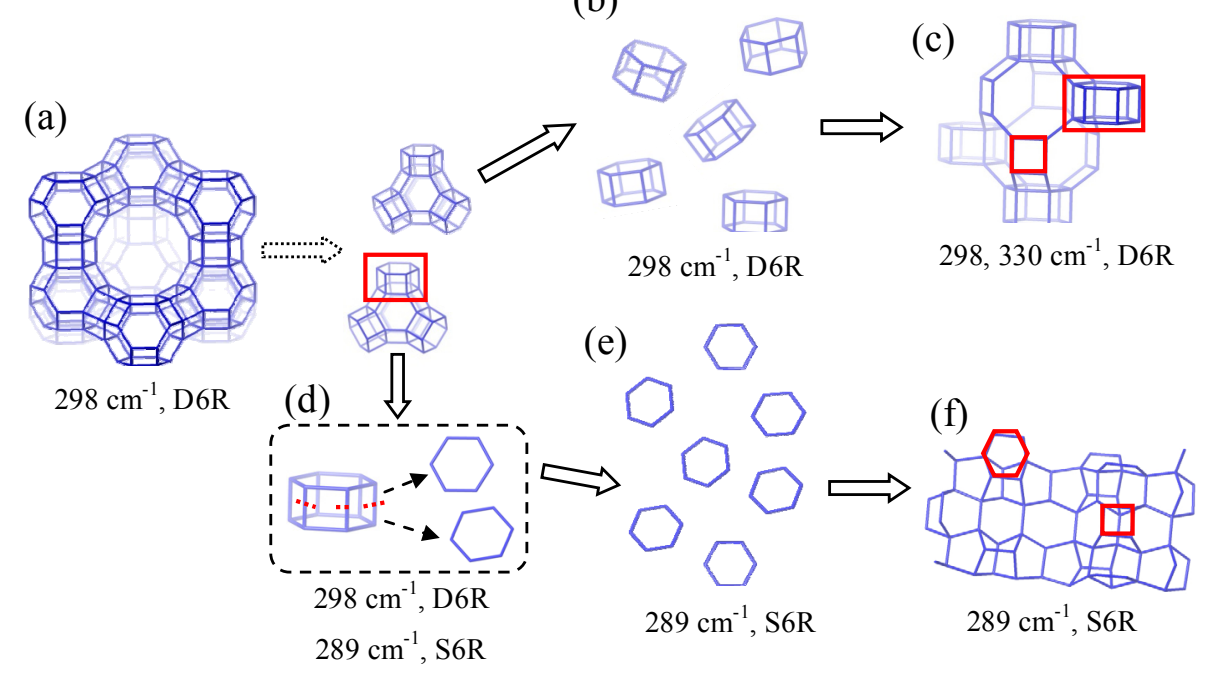

Fig. 5. The proposed pathways of the interzeolite transformation from FAU to (a-c) CHA and (a-f) MFI zeolites. 
troscopy. A nearly direct transformation of the D6R structure occurred when starting from FAU to the target CHA zeolite as they share the same basic composition unit (D6R). However, when the target zeolites do not contain the same basic structures, such as for the transformation of FAU to MFI, the D6R units are decomposed into two S6Rs as building blocks for further assembly and growth of the target product. The insights provided by this study may be important for further understanding of interzeolite transformation.

\section{References}

[1] A. Corma, Chem. Rev., 1995, 95, 559-614.

[2] M. E. Davis, Nature, 2002, 417, 813-821.

[3] H. Gies, B. Marler, Zeolites, 1992, 12, 42-49.

[4] S. Mintova, J. P. Gilson, V. Valtchev, Nanoscale, 2013, 5, 6693-6703.

[5] M. Moliner, F. Rey, A. Corma, Angew. Chem. Int. Ed., 2013, 52, 13880-13889.

[6] J. Shin, M. A. Camblor, H. C. Woo, S. R. Miller, P. A. Wright, S. B. Hong, Angew. Chem. Int. Ed., 2009, 48, 6647-6649.

[7] N. Nakazawa, T. Ikeda, N. Hiyoshi, Y. Yoshida, Q. Han, S. Inagaki, Y. Kubota, J. Am. Chem. Soc., 2017, 139, 7989-7997.

[8] E. M. Gallego, M. T. Portilla, C. Paris, A. Leon-Escamilla, M. Boronat, M. Moliner, A. Corma, Science, 2017, 355, 1051-1054.

[9] T. Maruo, N. Yamanaka, N. Tsunoji, M. Sadakane, T. Sano, Chem. Lett., 2014, 43, 302-304.

[10] N. Martin, Z. B. Li, J. Martínez-Triguero, J. H. Yu, M. Moliner, A. Corma, Chem. Commun., 2016, 52, 6072-6075.

[11] J. E. Schmidt, M. A, Deimund, D. Xie, M. E. Davis, Chem. Mater, 2015, 27, 3756-3762.

[12] H. Xu, Q. M. Wu, Y. Y. Chu, J. G. Jiang, L. Zhang, S. X. Pan, C. S. Zhang, L. F. Zhu, F. Deng, X. J. Meng, S. Maurer, R. McGuire, A. N. Parvulescu, U. Müller, F. S. Xiao, J. Mater. Chem. A, 2018, 6, 8705-8711.
[13] L. Van Tendeloo, E. Gobechiya, E. Breynaert, J. A. Martens, C. E. A. Krischhock, Chem. Commun., 2013, 49, 11737-11739.

[14] N. Funase, T. Tanigawa, Y. Yamasaki, N. Tsunoji, M. Sadakane, T. Sano, J. Mater. Chem. A, 2017, 5, 19245-19254.

[15] M. Itakura, K. Ota, S. Shibata, T. Inoue, Y. Ide, M. Sadakane, T. Sano, J. Cryst. Growth, 2011, 314, 274-278.

[16] C. Y. Hu, W. F. Yan, R. R. Xu, Acta Chim. Sin., 2017, 75, 679-685.

[17] Y. C. Shi, E. H. Xing, X. Z. Gao, D. Y. Liu, W. H. Xie, F. M. Zhang, X. H. $\mathrm{Mu}, \mathrm{X}$. T. Shu, Microporous Mesoporous Mater., 2014, 200, 269-278.

[18] W. Fan, M, Ogura, G. Sankar, T. Okubo, Chem. Mater., 2007, 19, 1906-1917.

[19] M. B. Park, Y. Lee, A. M. Zheng, F. S. Xiao, C. P. Nicholas, G. J. Lewis, S. B. Hong, J. Am. Chem. Soc., 2013, 135, 2248-2255.

[20] S. Prodinger, A. Vjunov, J. Z. Hu, J. L. Fulton, D. M. Canaioni, M. A. Derewinski, J. A. Lercher, Chem. Mater., 2018, 30, 888-897.

[21] S. A. Pelster, R. Kalamajka, W. Schrader, F. Schuth, Angew. Chem. Int. Ed., 2007, 46, $2299-2302$.

[22] B. B. Schaack, W. Schrader, F. Schuth, Angew. Chem. Int. Ed., 2008, 47, $9092-9095$.

[23] T. M. Davis, T. O. Drews, H. Ramanan, C. He, J. S. Dong, H. Schnablegger, M. A. Katsoulakis, E. Kokkoli, A. V. McCormick, R. L. Penn, M. Tsapatsis, Nat. Mater., 2006, 5, 400-408.

[24] A. I. Lupulescu, J. D. Rimer, Science, 2014, 344, 729-732.

[25] S. Mintova, N. H. Olson, V. Valthev, T. Bein, Science, 1999, 283, 958-960.

[26] Y. Zhao, H. B. Zhang, P. C. Wang, F. Q. Xue, Z. Q. Ye, Y. H. Zhang, Y. Tang, Chem. Mater., 2017, 29, 3387-3396.

[27] F. T. Fan, Z. C. Feng, C. Li, Chem. Soc. Rev., 2010, 39, 4794-4801.

[28] L. M. Ren, Q. Guo, H. Y. Zhang, L. F. Zhu, C. G. Yang, L, Wang, Z. C. Feng, C. Li, F. S. Xiao, J. Mater. Chem., 2012, 22, 6564-6567.

[29] N. Sheng, Y. Y. Chu, S. H. Xin, Q, Wang, X. F. Yi, Z. C. Feng, X. J. Meng, X. L. Liu, F. Deng, F. S. Xiao, J. Am. Chem. Soc., 2016, 138, 6171-6176.

[30] M. J. Frisch, G. W. Trucks, H. B. Schlegel, et al., Gaussian 09, Revision

\section{Graphical Abstract}

Chin. J. Catal., 2019, 40: 1854-1859 doi: S1872-2067(19)63287-0

Interzeolite transformation from FAU to CHA and MFI zeolites monitored by UV Raman spectroscopy

Juan Zhang, Yueying Chu, Xiaolong Liu, Hao Xu, Xiangju Meng *, Zhaochi Feng *, Feng-Shou Xiao *

Zhejiang University; Dalian Institute of Chemical Physics, Chinese Academy of Sciences; Wuhan Institute of Physics and Mathematic; Sun Yat-Sun University

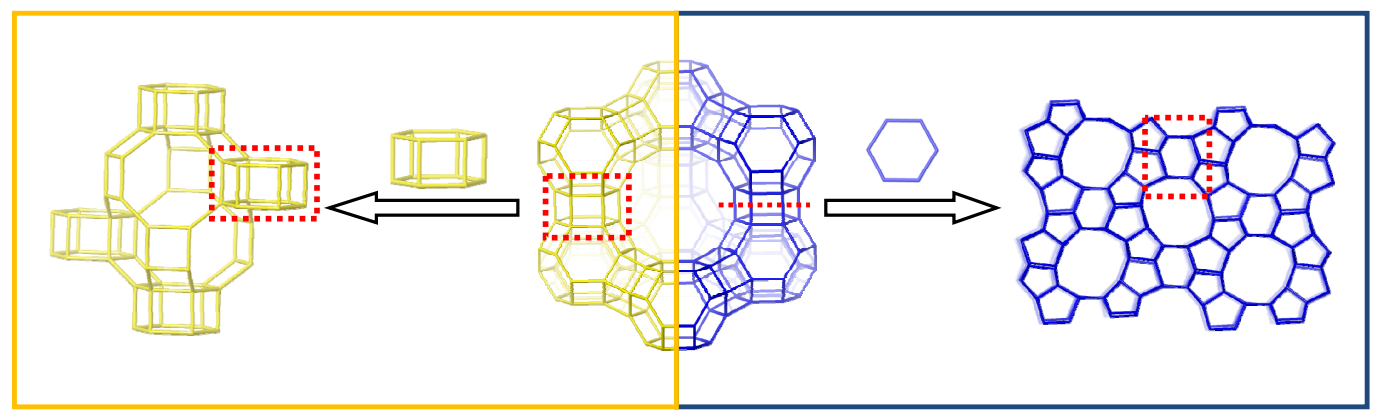

The illustration shows the behavior of double 6-membered rings (D6R) units of the FAU zeolite for the formation of the target CHA (yellow line) and MFI (blue line) zeolites, where the dotted-line squares indicate the key species (D6R and single 6-membered rings (S6R)) during interzeolite transformation. 
$B, 01,2010$.

[31] Y. Yu, G. Xiong, C. Li, F. S. Xiao, Microporous Mesoporous Mater., 2001, 46, 23-34.

[32] P. Li, T. Ding, L. P. Liu, G. Xiong, Mater. Charact,, 2013, 86, 221-231.

[33] P. K. Dutta, D. C. Shieh, M. Puri, J. Phys. Chem., 1987, 91, 2332-2336.

[34] F. T. Fan, Z. C. Feng, G. N. Li, K. J. Sun, P. L. Ying, C. Li, Chem. Eur. J., 2008, 14, 5125-5129.

[35] C. L. Angell, J. Phys. Chem., 1973, 77, 222-227.

[36] D. K. Arkhipenko, G. P. Valueva, T. N. Moroz, J. Struct. Chem., 1995, 36, 171-174.

[37] C. H. Sun, D. J. Srivastava, P. J. Grandinetti, P. K. Dutta, Microporous Mesoporous Mater., 2016, 230, 208-216.

[38] T. Ikuno, W. Chaikittisilp, Z. D. Liu, T. Iida, Y, Yanaba, T. Yoshikawa,
S. Kohara, T. Wakihara, T. Okubo, J. Am. Chem. Soc., 2015, 137, 14533-14544.

[39] B. Mihailova, V. Valtchev, S. Mintova, A. C. Faust, N. Petkov, T. Bein, Phys. Chem. Chem. Phys., 2005, 7, 2756-2763.

[40] L. M. Ren, Q. Guo, H. Y. Zhang, L. F. Zhu, C. G. Yang, L. Wang, X. J. Meng, Z. C. Feng, C. Li, F. S. Xiao, J. Mater. Chem., 2012, 22, 6564-6567.

[41] Q. M. Wu, X. Wang, G. D. Qi, Q. Guo, S. X. Pan, X. J. Meng, F. Deng, F. T. Fan, Z. C. Feng, C. Li, S. Maurer, U. Muller, F. S. Xiao, J. Am. Chem. Soc., 2014, 136, 4019-4025.

[42] Y. Y. Chu, G. C. Li, L. Huang, X. F. Yi, H. Q. Xia, A. M. Zheng, F. Deng, Catal. Sci. Technol., 2017, 7, 2512-2523.

[43] Y. Y. Chu, B. Han, A. M. Zheng, X. F. Yi, F. Deng, J. Phys. Chem. C, 2013, 117, 2194-2202.

\section{紫外拉曼光谱研究FAU到CHA和MFI分子篮的转晶过程 \\ 张 娟 ${ }^{\mathrm{a}}$, 褚月英 ${ }^{\mathrm{c}}$, 刘小龙 ${ }^{\mathrm{d}}$, 徐 好 ${ }^{\mathrm{a}}$, 冯兆池 ${ }^{\mathrm{b}, \$}$, 孟祥举 ${ }^{\mathrm{a},{ }^{*}}$, 肖丰收 ${ }^{\mathrm{a}, \#}$

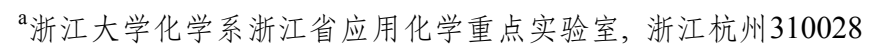 \\ ${ }^{\mathrm{b}}$ 中国科学院大连化学物理研究所催化基础国家重点实验室, 辽宁大连 116023 \\ ${ }^{c}$ 中国科学院武汉物理与数学研究所波谱与原子分子物理国家重点实验室, 湖北武汉 430071 \\ $\mathrm{d}$ 中山大学材料科学与工程学院, 广东广州 510275}

摘要: 分子篮是一类广泛运用于工业催化的多孔无机微晶材料, 尽管其制备方式和晶化机理的报道很多, 但是大多局限于 无机凝胶合成体系. 近年来, 分子篮间的转晶生长引起了广泛关注, 尤其是以高硅铝比的FAU分子篮作为原料进行转晶, 因其结构中含有大量有序连接的双六元环(D6R)单元, 前述研究多认为D6R结构在分子筛间的转晶过程中起着重要作用, 但是这种作用并未得到详尽描述. 一直以来, 紫外拉曼光谱都被认为是表征分子篮结构单元的有力手段, 它可用以鉴定分 子篎骨架或半骨架结构的特征振动. 因此, 本文运用紫外拉曼光谱技术监测由FAU分子篮转晶成CHA和MFI的晶化过程, 并采用DFT计算进行辅助证明, 观察了D6R结构的转晶行为.

紫外拉曼光谱结果表明, FAU结构中的D6R物种在分子簰间的转晶过程中对目标分子篮的形成起着关键作用. 在FAU 转晶成CHA的晶化过程中, 紫外拉曼光谱表明FAU和CHA上均出现 $300 \mathrm{~cm}^{-1}$ 的振动峰, 该峰可归属于D6R结构的弯曲振动. 在转化过程中, FAU和 $\mathrm{CHA}$ 的结晶度分别呈现出明显的降低和增长的趋势, 而D6R振动峰的强度在实验误差允许范围内基 本保持不变, 表明尽管体系中存在着FAU溶解和CHA生成的动态平衡, 但是D6R结构却始终保持相对稳定, 这种现象可归 因于二者都含有相同的结构单元D6R, 这种结构相似性使得D6R物种更易于保持结构完整性从而进行直接转化.

然而, 在FAU转晶成MFI的晶化过程中, 紫外拉曼光谱表明FAU的 $300 \mathrm{~cm}^{-1}$ 振动峰的强度随着晶化时间的延长而不断 减弱, 与此同时, MFI归属于单六元环(S6R)的 $289 \mathrm{~cm}^{-1}$ 振动峰的强度在短时间内迅速增大到最大值, 而归属于四元环 (4R)和 五元环 (5R)的 433,475 和 $377 \mathrm{~cm}^{-1}$ 振动峰的强度均与MFI结晶度的增长呈现相同趋势. 这表明转化过程中FAU结构的D6R 物种将更倾向于被分解成两个S6R而非三个 $4 \mathrm{R}, 4 \mathrm{R}$ 和 $5 \mathrm{R}$ 只能在MFI骨架结构形成后被观察到, 即发挥作用的基本结构单元 是 S6R而非 $5 \mathrm{R}$, 分解出来的 S6R 再用以进一步组装成MFI结构. 为进一步验证D6R结构易于分解成S6R, 采用DFT计算对从 D6R 结构分解成两个S6R 和三个 $4 \mathrm{R}$ 的生成焓进行了比较. 结果表明, 分解成两个 $S 6 R$ 的生成焓 $(-16.3 \mathrm{kcal} / \mathrm{mol})$ 明显低于分 解成三个 $4 \mathrm{R}$ 的生成焓 $(-4.6 \mathrm{kcal} / \mathrm{mol})$, 说明D6R生成两个 $\mathrm{S} 6 \mathrm{R}$ 的可能性更大, 这恰好与紫外拉曼光谱的结果一致. 上述研究 将有助于更好地理解分子篮间的转晶行为.

关键词: 分子笁转晶; 紫外拉曼光谱; 密度泛函理论计算; 双六元环; 分解和再组装

收稿日期: 2019-01-10. 接受日期: 2019-02-25. 出版日期: 2019-12-05.

*通讯联系人. 电话/传真: (0571)8273698; 电子信箱: mengxj@zju.edu.cn

\#通讯联系人. 电话/传真: (0571)8273698; 电子信箱: fsxiao@zju.edu.cn

通讯联系人. 电话/传真: (0411)84694447; 电子信箱: Zcfeng@zju.edu.cn

基金来源：国家重点研发计划(2017YFB0702800); 国家自然科学基金(2152780065, 91634201，21720102001); 中国科学院战略性 先导科技专项(XDB17000000).

本文的电子版全文由Elsevier出版社在ScienceDirect上出版(http://www.sciencedirect.com/science/journal/18722067). 